\title{
Microbial activity of some heterocyclic Schiff bases and metal complexes: A review
}

\author{
Thierry Y Fonkui ${ }^{1}$, Monisola I lkhile ${ }^{2}$, Derek T Ndinteh ${ }^{2}$, Patrick B Njobeh ${ }^{1 *}$ \\ ${ }^{1}$ Department of Biotechnology and Food Technology, ${ }^{2}$ Department of Applied Chemistry, University of Johannesburg PO Box \\ 17011, Doornfontein Campus 2028, South Africa
}

*For correspondence: Email: pnjobeh@uj.ac.za; mikhile@uj.ac.za; Tel: +27-11-559-6803

\begin{abstract}
Microbial resistance to current drugs associated with food spoilage and complications in diseases' treatment have resulted in increased mortality rate globally. Schiff bases are an important versatile class of organic compounds with notable pharmacological properties for various industrial applications. They are usually synthesized from a condensation reaction between a primary amine and a carbonyl. They have a wide range of activities against microbes and demonstrate good antimicrobial activity against fungi, bacteria, parasites, and viruses. The antimicrobial activity of Schiff base ligands is usually better upon metal complexation as a result of their chelating behaviour. The synthesis of Schiff bases and their metal complexes are well-documented. Therefore, it is important to categorize and compile them according to their biological significance. In this review, the antibacterial, antifungal, antiparasitic and antiviral activity of some selected heterocyclic Schiff bases and their metal complexes are discussed.
\end{abstract}

Keywords: Heterocyclic Schiff bases, Metal complexes, Antibacterial, Antifungal, Antiparasitic, Antiviral

This is an Open Access article that uses a funding model which does not charge readers or their institutions for access and distributed under the terms of the Creative Commons Attribution License (http://creativecommons.org/licenses/by/4.0) and the Budapest Open Access Initiative (http://www.budapestopenaccessinitiative.org/read), which permit unrestricted use, distribution, and reproduction in any medium, provided the original work is properly credited.

Tropical Journal of Pharmaceutical Research is indexed by Science Citation Index (SciSearch), Scopus, International Pharmaceutical Abstract, Chemical Abstracts, Embase, Index Copernicus, EBSCO, African Index Medicus, JournalSeek, Journal Citation Reports/Science Edition, Directory of Open Access Journals (DOAJ), African Journal Online, Bioline International, Open-J-Gate and Pharmacy Abstracts

\section{INTRODUCTION}

\section{Schiff bases - definition and concepts}

Schiff bases are compounds containing carbonnitrogen double bond generally known as azomethine or imine linkage. They were named after their discovery in 1864 by an Italian naturalized chemist, Hugo Joseph Schiff [1]. They are structure-based compounds in which the oxygen atom of the carbonyl group $(\mathrm{C}=\mathrm{O})$ of an aldehyde or ketone is replaced by the nitrogen of primary amine [2]. Knowledge of Schiff bases dates as far back as 1864 when the Hugo Schiff reported the successful formation of an imine linkage for the first time [3]. Schiff bases form a class of important organic compounds and represent the most utilized group of organic molecules. Compounds containing double bond carbon-nitrogen functional group in their molecules have contributed significantly to progress in science, especially medicinal chemistry. They are useful in day-to-day life because of the unlimited potency of the azomethine group and ease in their formation.

\section{Synthesis of Schiff bases}

Schiff bases are generally formed as a result of the chemical reaction between a primary amine 
$\left(\mathrm{R}-\mathrm{NH}_{2}\right)$ and a carbonyl group (aldehyde: R$\mathrm{CH}=\mathrm{O}$ or ketone $\mathrm{R}_{1} \mathrm{R}_{2} \mathrm{C}=\mathrm{O}$ ) in the presence of chemical catalysts and under constant heat [4]. The chemical equation is presented in Figure 1.

$$
\begin{aligned}
& \mathrm{R}_{2} \backslash \mathrm{C}=\mathrm{O} \\
& \text { Carbonyl } \\
& \text { Amine }
\end{aligned}
$$

$R_{1}, R_{2}$, and/or $R_{3}=$ alkyl or aryl

Figure 1: General procedure for Schiff bases formation

Compounds containing azomethine functional groups could be obtained from various natural and non-natural sources; they can also be synthesized in the laboratory. Several methods have been applied to synthesize Schiff bases. Organic methods, commonly known as the classical method usually take place in alcoholic conditions. This is usually followed by the removal of solvents, mainly in the case of aprotic dipolar solvent with a high boiling point [5]. Other synthetic methods do not involve the use of chemical solvents. Microwave-assisted methods have been used to synthesize Schiff base ligands [6-9] and are documented as green synthesis. Bhagat et al [10] and Salve et al [11] have successfully synthesized Schiff base compounds using water as a solvent. The mechanism of Schiff base formation involves a nucleophilic attack by the amine on the electrophile site with the formation of a tetrahedral intermediate. This process, therefore, leads to the liberation of water and the formation of imine group irrespective of the routes or methods adopted (Figure 2).

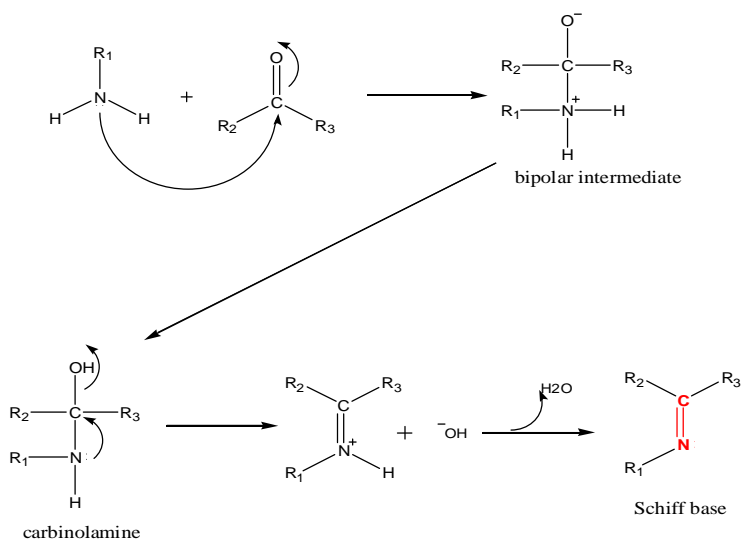

Figure 2: Mechanism of Schiff bases synthesis

\section{Biological applications of Schiff bases}

Over the past decades, interest in Schiff bases has increased significantly as demand for new compound formulations with desired functionalities rises. Schiff bases possess excellent characteristics due to the carbonnitrogen double bond in their structure. The beneficial properties of Schiff base compounds are not limited to the azomethine bond, but are structurally enhanced by numerous scaffolds, such as aromatic and substituted aromatic compounds. Besides, the presence of electronrich species such as nitrogen $(\mathrm{N})$, oxygen $(\mathrm{O})$, sulfur (S) in the Schiff base molecule are reported to greatly increased their applications $[12,13]$. For instance, Schiff bases derived from salicylaldehyde derivatives with $-\mathrm{OH}$ group in ortho and para positions are of interest mainly due to the existence of $\mathrm{O}-\mathrm{H} \cdots \mathrm{N}$ and $\mathrm{O} \cdots \mathrm{H}-\mathrm{N}$ type hydrogen bonds, which undergo excited state tautomerization between enol-imine and ketoenamine [14]. In addition, the presence of nucleophile groups is very important in chelating metal ions, which have found intensive applications in drug discovery, catalysis and chromatography applications [15].

Schiff bases are structurally diversified and very useful in the scientific body. The imine properties of Schiff bases have gained the attention of many scientists worldwide due to their multiple facet applications. They are used as dyes, chelating agents, antimicrobial agents, and as a prototype for antibiotics development [16-18]. Imines Schiff bases have been publicized as good antibacterial, antifungal, antiviral, antiinflammatory, antimalarial, and antioxidants agents [19-22]. They owe their multifunctional properties to countless aldehydes/ketones and amines used in condensation reactions, including mainly, but not limited to, aromatic and heterocyclic rings.

\section{Heterocyclic Schiff bases}

In the development of novel compounds with biologically active properties, Schiff bases derived from heterocyclic rings present many advantages. The common heteroatoms found are usually nitrogen, oxygen, and sulfur (NOS). Among the various types of heterocycle molecules studied [23,24], nitrogen $(\mathrm{N})$ contained compounds such as benzimidazole and its derivatives represent groups of important chromophores with desirable biological properties [25,26]. Benzimidazole is a bicyclic carbon and nitrogen-containing heterocycles with a broad spectrum of pharmacological activity [27]. Benzimidazole nuclei are very important pharmacophores with increasing attention in modern drug discovery [28]. Literature shows that many human pathogens and microbial agents are very sensitive to Schiff bases with benzimidazole moiety. These include bacteria [29,30], fungi [31], and viruses [32,33], which are 
discussed subsequently in this review. Moreover, benzimidazole Schiff bases have also been reported to have antioxidant, anti-inflammatory, analgesic, antitumor, anticancer, and inhibitory properties [34-39].

\section{Antibacterial activity}

Bacteria threatening life and affecting the health status of people living in South Africa and regions beyond include both Gram-negative and Gram-positive bacteria. The uptake or the ingestion of water and/or food contaminated with bacteria such as Salmonella typhi, Escherichia coli including Clostridium, Pseudomonas and Bacillus species can affect human and animal health causing diseases such as typhoid, fever, and diarrhoea [40-42]. Therapeutic measurements to address these infections witness many drawsbacks due to microbial resistance [43]. Schiff bases are considered good antibacterial agents and their biological activities have been enhanced by metal complexations as clearly documented in the literature with bacteria responding differently.

Shanty et al [44] synthesized seven different heterocyclic Schiff bases and investigated their antibacterial activity. Accordingly, the Schiff base ligands were obtained by reacting carbonyls (thiophene-2-carboxaldehyde and pyrrole-2carboxaldehyde) with some derivatives of aminophenol (2-aminophenol, 2-amino 4nitrophenol, 2- amino benzimidazole, or 2-amino 4-methylphenol) in hot methanol. Agar diffusion method was followed and minimum inhibitory concentration (MIC) established in assessing the antimicrobial property of the prepared ligands against the bacteria: Salmonella typhi, Bacillus coagulans, Bacillus pumills, Escherichia coli, Bacillus circulans, Pseudomonas, Clostridium and Klebsilla pneumonia.

Test compounds showed low to moderate activity to other strains studied as well and exhibited no cytotoxic effect against Escherichia coli. Compound 21 (Figure 3) was the most potent ligand with $17 \mathrm{~mm}$ diameter zone of inhibitory growth and MIC of $25 \mu \mathrm{g} / \mathrm{mL}$ against Salmonella typhi. The low bactericidal activity recorded for other ligands could be attributed to their interactions with the lipids content of the bacterial cell walls or their ribosomes content [44].

The pharmacological property of the candidate drugs is directly associated with the physiological conditions and chemical properties of both the test microorganisms and compounds. Thus, the penetration of candidate drugs through the cell membrane into the microbial cell may depend on the degree of hydrophobicity. The same way that a polar molecule will dissolve a polar compound; the hydrophobic nature of the bacteria cell membrane will enhance the interaction with nonpolar compounds and favour their penetration into the cytoplasm resulting in cell death. Shanty and his colleagues [44] also noted the resistance of Gram-negative bacterium Escherichia coli against all prepared ligands due to the lipopolysaccharide protective layer of the bacterial cell membrane. This protective coat only allows for lipid soluble compounds interaction at the membrane surface and as such, reduces the amount of test compound flowing into the cell.

Heterocyclic Schiff bases consisting of 2hydrazino-5-[substituted phenyl]-1,3,4-thiadiazole and 2-hydroxyacetophenone/benzaldehyde/indoline-2, 3-dione with their zinc(II) complexes have been successfully prepared and characterized by Singh et al [45].

The biological activity of the compounds and their corresponding metal complexes were studied. Bacteriostatic property by disc diffusion method and bactericidal activity by microdilution technique were selected to screen the effect of these compounds on bacteria. The antimicrobial activity of the metal-free ligands and the complexes was tested against Bacillus subtilis and Escherichia coli. All synthesized Schiff bases (Compounds 2.3-2.8) possessed good antibacterial activity with increased potency observed in metal chelating ligands. Six 2-Chloro substituted ligands with their metal analogs (Compounds 2.3-2.8) were more active (MIC $325-425 \mu \mathrm{g} / \mathrm{mL}$ ), than other substituted ligands (MIC $330-455 \mu \mathrm{g} / \mathrm{mL}$ ), against these microbes. Structure-activity relationship of the ligands revealed that the additional heterocyclic ring (indoline-2,3-dione) significantly increased the pharmacological potency of Compound 2.8 making it more active against all bacteria studied.

The in vitro antibacterial activities of novel tridentate Schiff bases and their cobalt(II) complexes were recently evaluated against five antibiotic-resistant strains, i.e., Pseudomonas aeruginosa, Escherichia coli, Proteus mirabilis, Citrobacter amalonaticus and Klebsiella pneumoniae following the disc diffusion method [46]. All tested compounds possessed antibacterial activity, showing considerable growth inhibitory zones against the isolates. Schiff bases and their complexes have no effect on $K$. pneumoniae strain from these extended spectrum $\beta$-lactamase isolates. For compounds 2.9 and 2.10 and their respective cobalt complex (Compound 2.11) shows similar observations 
<smiles>Oc1ccccc1/N=C/c1cccs1</smiles><smiles>Oc1ccccc1/N=C/c1ccc[nH]1</smiles><smiles>[R]C1=NN=C(N/N=C(\C)c2ccccc2O)C1</smiles><smiles>[R]C1=NN=C(N/N=C2\C(=O)Nc3ccccc32)C1</smiles>
$\mathrm{R}=2-\mathrm{ClC}_{6} \mathrm{H}_{4}$ $\mathrm{R}=4-\mathrm{ClC}_{6} \mathrm{H}_{4}$ $2.5 \mathrm{~N}$

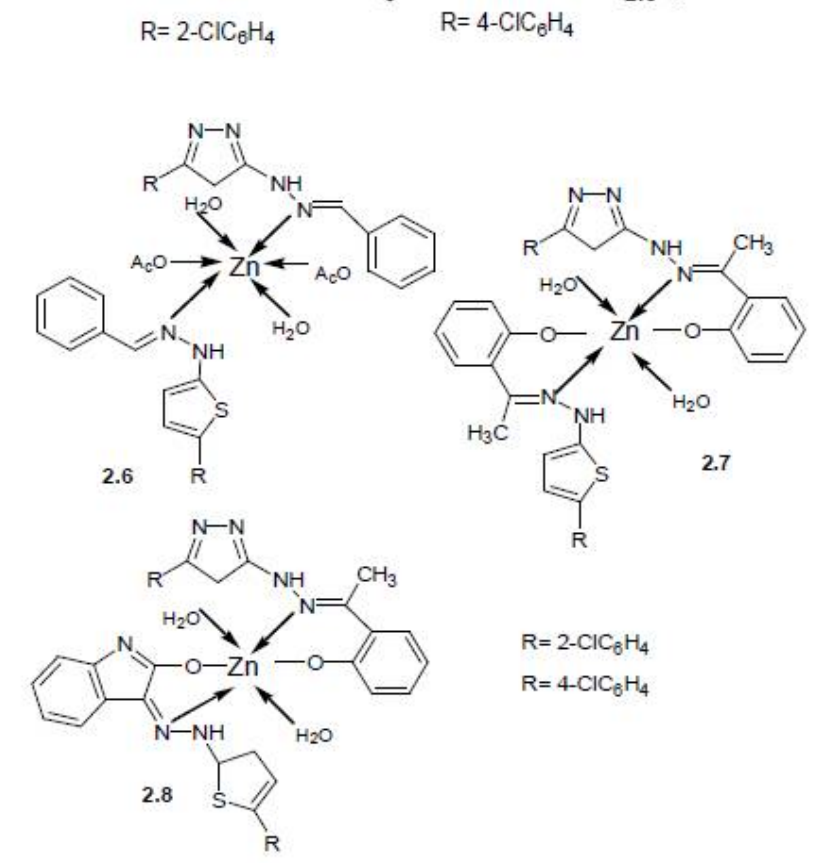<smiles>CCOC(=O)c1c(/N=C/c2cc(Br)ccc2O)sc2c1CCCC2</smiles><smiles>CCOC(=O)c1c(/N=C/c2c(O)ccc3ccccc23)sc2c1CCCC2</smiles>

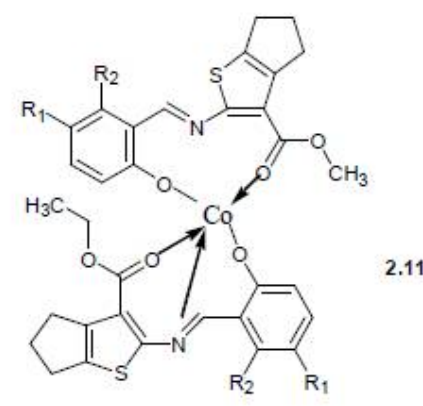

$\mathrm{R}_{1}$ and $\mathrm{R}_{2}=\mathrm{H}$ $\mathrm{R}_{1}=\mathrm{Cl}$ and $\mathrm{R}_{2}=\mathrm{H}$ $R_{1}=B r$ and $R_{2}=H$ $\mathrm{R}_{1}-\mathrm{R}_{2}=-(\mathrm{CH}) \mathrm{a}-$<smiles>CC(=O)NS(=O)(=O)c1ccc(N2Cc3ccccc3O[Al](N(c3ccc(S(=O)(=O)NC(C)=O)cc3)c3ccc(S(=O)(=O)NC(C)=O)cc3)Oc3ccccc3O2)cc1</smiles><smiles>CC(=[18O])CN(C(=O)C=C(C)C)c1ccc(S(N)(=O)=O)cc1</smiles>

Figure 3: Chemical structures of some Schiff base compounds and their metal complexes with antibacterial activity

with metallo $\beta$-lactamase producing $P$. mirabilis, showing no zone of inhibition. The most sensitive strain was Citrobacter amalonaticus, with zones of inhibition ranging between $\phi 13$ and $\phi 22 \mathrm{~mm}$ against cobalt complexes, produced by metallo $\beta$-lactamase. The enhanced antimicrobial activity of cobalt complexes against the tested isolates was attributed to the concept of chelation. Chelation increases the hydrophobic property of the ligand, achieved as positive charges on the metal are partially shared with the donor atoms present in the ligands which in turn favor $\pi$ electron delocalization over the metal complex formed. Hence, the lipophilic character of the metal complex increases and favors its permeation more efficiently through the lipid layer of the micro-organisms [46].

Schiff bases derived from sulphanilamide and related copper(II) complexes were synthesized by Saheli et al [47] and studied against Grampositive (Staphylococcus aureus and
Enterococcus faecalis) and Gram-negative (Klebsiella pneumoniae and Escherichia coll) human pathogenic bacteria. The tested Schiff bases were obtained by refluxing sulfacetamide, sulfabenzamide and sulphanilamide with salicylaldehyde and acetylacetone in alcoholic solutions and by microdilution assay, MIC and minimum bactericidal concentration (MBC) of the ligands were evaluated together with their copper(II) based complexes with kanamycin as a positive control. The ligands (compounds 2.12 to 2.14) displayed the same potent antibacterial activity against tested strains with compound 2.13 standing out with the highest activity, recording a MIC $22.8 \mu \mathrm{g} / \mathrm{mL}$. The activity of compound 2.13 improved on complexation (compound 2.15) as it discloses a 2-fold strength (MIC, $11.4-22.8 \mu \mathrm{g} / \mathrm{mL}$ ) against the strains. Compound 2.16 has a broad spectrum activity inducing bacteria cell death.

Trop J Pharm Res, December 2018; 17(12): 2510 
The increased potency of Schiff base compounds after metal chelation can be explained by the Overtone's concept [48] and the Tweedy's theory [49]. The theory describes that chelation reduces the polarity of metal ions to a greater extent due to the overlapping of the ligand orbital and partial sharing of positive charge of the metal ion with donor groups and delocalization of electron into the whole chelate ring [50]. Another important factor controlling antimicrobial activity is lipophilicity. High lipophilicity generally leads to compounds with high rapid turnover [51]. As lipophilicity increases so do cell membrane permeability, which may result in an alteration in cellular metabolic activities and cytoplasmic leakage leading to cell death.

\section{Antifungal activity}

Fungi are plant pathogens, cause a wide range of diseases and are also the principal sources of secondary metabolites including mycotoxins [52]. Food contamination by fungi and attendant mycotoxins pose a threat to human and animal health and also compromise the economy seriously. Physical and biological approaches include heat treatment, washing, the use of bacteria and enzymes. Fungi and mycotoxins degradation are used to control fungal propagation [53]. The use of inorganic compounds such as silica-based materials, i.e., binders and their chemical modifications to mitigate fungal contamination have been documented [54,55]. However, their health implications and appearances in commodities often compromise food quality. For these reasons, the continuous need to develop t novel compounds against microbial resistance to commercial standard drugs cannot be overemphasized.

Recently, Maddila et al reported on the synthesis and antifungal activity of new Schiff bases derived from benzothiazole pyrimidine derivatives.[56] Broth dilution method was used to determine the MIC of the ligands on Aspergillus flavus, A. fumigatus, Candida albicans, Penicillium marneffei and P. mucor. All tested organisms were sensitive to the ligands that exhibited mildly to good antifungal activity at a concentration range of $100-200 \mu \mathrm{g} / \mathrm{mL}$. It was observed that the para-substitution was preferred to ortho substitution. Compounds 2.1-19 (Figure 4) exhibited the same if not, greater antifungal activity (MIC $12.5-25 \mu \mathrm{g} / \mathrm{mL}$ ) when compared to ciprofloxacin (MIC 12.5-50 $\mu \mathrm{g} / \mathrm{mL}$ ) used as a standard. The abundance of aromatic rings contained in these compounds with electronwithdrawing substituents disclosed their biological importance over compounds studied under similar conditions. From the seven Schiff base ligands prepared, compound $\mathbf{2 . 1 8}$ was the most potent, affecting the metabolic activity of all tested fungal strains. Compound 2.18 displayed greater activity (MIC $12.5 \mu \mathrm{g} / \mathrm{mL}$ ) than standard drug clotrimazole (MIC $25 \mu \mathrm{g} / \mathrm{mL}$ ) against tested strains. These results present the ligand to be two against $A$. flavus and $A$. fumigatus and four times more potent against $C$. albicans and $P$. mucor than clotrimazole. The potency of the compound could be directly associated with high lipophilicity indexes ranging between $5.4-6.17$ [29].

The antifungal activity of a series of Schiff bases derived from 1,3-benzothiazole-2-yl-hydrazones was evaluated against Aspergillus niger, Rhizopus oryzae and Candida albicans following the disc diffusion method [57]. All compounds were prepared in hot ethanol by mixing 6-chloro2-benzothiazol-2-yl-hydrazine with different aromatic carbonyls. Compound 2.20 and 2.21 (Figure 4), amongst others, showed similar activities against $A$. niger, whereas Compound 2.20 was highly potent against Rhizopus oryzae and Candida albicans. The improved activity of these compounds is due to the substitution of electron donating group $\left(-\mathrm{CH}_{3}\right)$ in para position and electron withdrawing group $\left(-\mathrm{NO}_{2}\right.$ and $\left.-\mathrm{Br}\right)$ in the same position.

Schiff bases derived from glycylglycine with imidazole-2-carboxaldehyde and indole-3carboxaldehyde and their zinc(II) complexes were synthesized and assessed for their antifungal activities [58]. The ability of the ligands and their complexes to induce fungal cell death following disc diffusion method was studied against $A$. niger, $A$. flavus, Rhizopus stolonifer, Rhizoctonia bataicola and $C$. albicans with nystatin used as a standard antifungal drug. In vitro antifungal analysis showed moderate activity against the tested strains [58]. Compound 2.22 (Figure 4) showed low activity against $A$. niger as compared to its analog Compound 2.23. $\mathrm{Zn}$ (II) complexes of the ligands (2.24 and 2.25) (Figure 4) showed higher activity compared to the free ligands. The uncoordinated atoms with the ligands enhance the activity of the complexes. Zinc ion increased the fungistatic property of the parent ligands as it binds easily at the cell wall membrane and, therefore, alters the cell's life and inhibits translation, which result in limited cell growth or cell death [59]. Chelation significantly reduced the polarity of $\mathrm{Zn}$ (II) ion by sharing its positive charge with ligand's electron donor groups, hence, increases the compound's permeability through the bacterial cell membrane into the cell. 
<smiles>Nc1c(-c2nc3ccccc3s2)c(-c2ccc(Cl)cc2)nc2nc(N/N=C/c3ccc(F)cc3)[nH]c(=O)c12</smiles>

2.17<smiles>Nc1ccc(/C=N/Nc2nc3nc(-c4ccc(Cl)cc4)c(-c4nc5ccccc5s4)c(N)c3c(=O)[nH]2)cc1</smiles>

2.19<smiles>C/C(=N/Nc1nc2ccc(Cl)cc2s1)c1ccc(Br)cc1</smiles><smiles>O=C(O)CNC(=O)C/N=C/C1=NCCN1</smiles>

2.22<smiles>C/C(=N/Nc1nc2ccc(Cl)cc2s1)c1ccc([N+](=O)[O-])cc1</smiles><smiles>Nc1c(-c2nc3ccccc3s2)c(-c2ccc(Cl)cc2)nc2nc(N/N=C/c3ccc([N+](=O)[O-])cc3)[nH]c(=O)c12</smiles>

2.21<smiles>O=C(O)CNC(=O)CN=Cc1nc2ccccc2[nH]1</smiles>

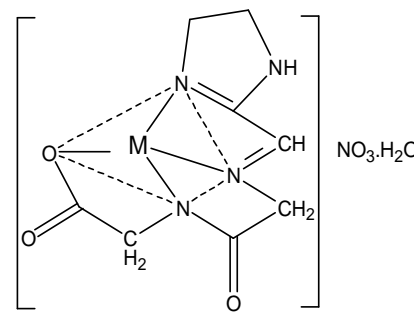

2.24

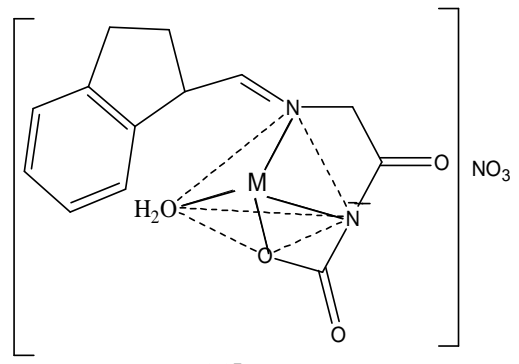

2.25

Figure 4: Chemical structures of some Schiff base compounds and their metal complexes with antifungal activity

\section{Antimalarial activity}

Over $40 \%$ of the world's population is exposed to malaria parasites due to increase of vectors' resistance to pesticides, the spread of drugresistant malaria parasites, and the toxicity of current antimalarial drugs, thus stimulating the need to develop effective novel and less toxic antimalarial drugs with different mechanisms of action. Azomethine $(\mathrm{C}=\mathrm{N})$ contained compounds are potential molecules that alleviate the problem of drug resistance. Schiff bases derived from sulphonamide and its derivatives together with those containing thiosemicarbazone moieties have been reported as good antimalarial parasites [60,61].

A series of fifteen Schiff bases derived from aromatic sulphonamides and analogs have been screened as inhibitors of Plasmodium falciparum carbonic anhydrase enzyme, indispensable to the biosynthetic pathway of pyrimidine, whose metabolic activity in malaria parasites can be found here [62]. The effect of these Schiff bases on Plasmodium enzyme was studied and the activity was compared to clinical drug acetazolamide. Authors suggested that the antimalarial activity of the compounds depended mainly on the nature of the substituted aromatic aldehydes used in the formation of the ligands. Sulphonamide derived Schiff bases with substituted (2-methoxyphenyl-; 2- or 4chlorophenyl-; 2- or 4-hydroxyphenyl- and 3methoxy-4-hydroxy-5-bromophenyl) aldehydes were very potent inhibitors of carbonic anhydrase enzyme, among others. Compounds 2.26-2.29 (Figure 5) inhibited parasite activity with an affinity constant $\left(\mathrm{K}_{\mathrm{I}}\right)$ ranging from 0.54-1.23 $\mu \mathrm{g} / \mathrm{mL}$, whereas, Compounds 2.30 and 2.32 (Figure 5) were the most potent derivatives with $K_{1}$ between 80 to $0.5 \mathrm{ng} / \mathrm{mL}$ against carbonic anhydrase enzyme. The unsubstituted compound 2.31 also displayed good antimalarial activity. At $K_{l}(80 \mathrm{ng} / \mathrm{mL})$, the compounds were four times more effective when compared to acetazolamide $\left(\mathrm{K}_{\mathrm{l}}, 315 \mathrm{ng} / \mathrm{mL}\right)$.

Antimalarial activity of a series of Schiff base compounds with hydrazine scaffold obtained by a condensation reaction between hydrated hydrazine and different aldehydes was studied against chloroquine-sensitive strain 3D7 and the chloroquine-resistant K1 strain of Plasmodium 


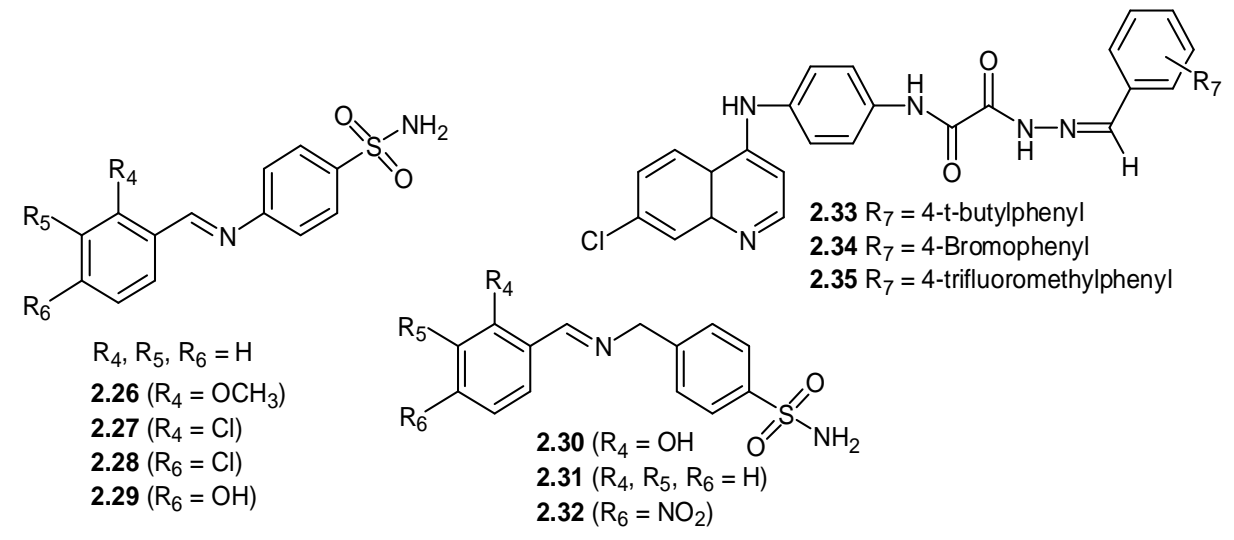<smiles>Oc1ccc(/N=C/c2cccc(CN3CCOCC3)c2O)cc1</smiles>

2.36<smiles>CCN(CC)c1ccc(/N=C/c2cccc(CN3CCOCC3)c2O)cc1</smiles>

2.37<smiles>Oc1ccccc1/N=C/c1cccc(CN2CCOCC2)c1O</smiles>

2.38<smiles>Oc1c(/C=N/c2ccccc2/N=C/c2cccc(CN3CCOCC3)c2O)cccc1CN1CCOCC1</smiles>

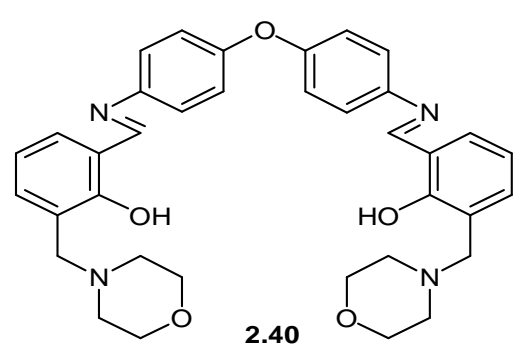

Figure 5: Chemical structures of some selected antimalarial Schiff base compounds

falciparum with chloroquine used as a reference antiplasmodial drug [63]. The studied compounds displayed good activity when compared to chloroquine.

Compounds 2.33, 2.34 and 2.35 (Figure 5) showed good antimalarial activity against the tested 3D7 strain with $\mathrm{IC}_{50}$ ranging from 19.69 to $25.38 \mathrm{ng} / \mathrm{mL}$.

Compound 2.33 was highly cytotoxic to the parasites with $\mathrm{IC}_{50} 19.69$ and $51.96 \mathrm{ng} / \mathrm{mL}$, respectively, when compared to chloroquine $\left(\mathrm{IC}_{50}\right.$ $495.94 \mathrm{ng} / \mathrm{mL}$ ). Its analogs, compounds 2.34 and 2.35 exhibited similar potency against malaria parasites, inducing cell death at $\mathrm{IC}_{50}$ of 20.78 and $85.68 \mathrm{ng} / \mathrm{mL}$ and $\mathrm{IC}_{50}$ of 25.38 and $22.52 \mathrm{ng} / \mathrm{mL}$ against strains 3D7 and $\mathrm{K} 1$, respectively. Structure-activity relationship of the ligands disclosed that the higher antiplasmodial activity of the ligands against the parasites was conferred to the t-butyl group in para of arylidene moiety (2.33), the 4-bromo- (2.34) and 4trifluoromethyl-substituted (2.35) compounds. The highly hydrophobic nature of these ligands induced by the aliphatic moieties increases their lipophilicity properties and facilitates their movement across the bilayer membrane. These observations encourage the search for novel antimalarial agents with substituted arylidene and heterocycles.

Jarrahpour et al [64] reported the synthesis and biological application of novel Schiff bases bearing morpholine scaffold. The compounds were prepared in hot ethanol as a mixture of 2hydroxy-3-(morpholinomethyl) benzaldehyde with some mono and bis-aromatic amines. The in vitro antimalarial activity of the ligands was investigated against chloroquine-resistant $P$. falciparum $\mathrm{K} 14$ following the broth microdilution assay. Data recorded showed that compounds 2.36 - 2.40 (Figure 5) were very active, inhibiting the growth of this parasite and exhibited good to 
<smiles>[Z14][X]</smiles>

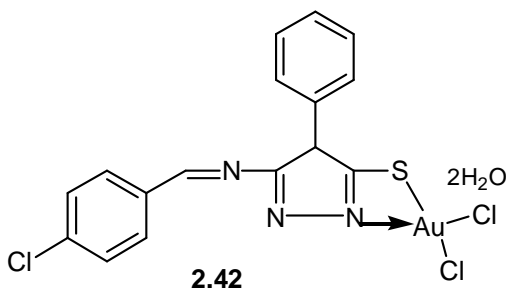<smiles>[Z11]#CSC1=NN=C(N=Cc2ccc(Cl)cc2)C1c1ccccc1</smiles>

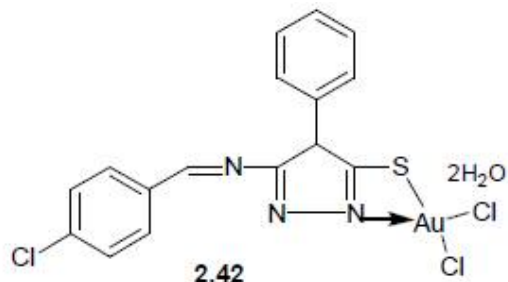

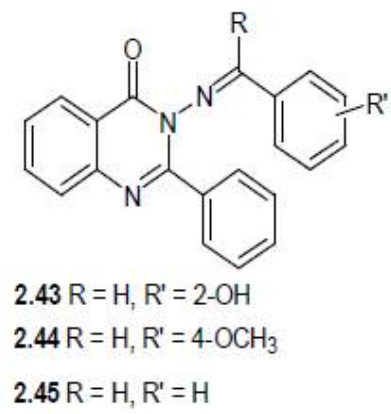<smiles>[R]C([R])=Nc1nc(NC2CC2)c2ncn(C3C=CC(CO)C3)c2n1</smiles>

$2.46 \mathrm{R}=\mathrm{H}, \mathrm{R}_{1}=2$-Nitrophenyl $2.47 \mathrm{R}=\mathrm{H}, \mathrm{R}_{1}=4-$ Nitrophenyl $2.48 \mathrm{R}=\mathrm{H}, \mathrm{R}_{1}=4$-Methylphenyl $2.49 \mathrm{R}=\mathrm{H}, \mathrm{R}_{1}=4$-Methoxyphenyl $2.50 \mathrm{R}=\mathrm{H}, \mathrm{R}_{1}=4$-Dimethylaminophenyl $2.51 \mathrm{R}=\mathrm{H}, \mathrm{R}_{1}=2$-Hydroxy-4-methoxyphenyl

Figure 6: Chemical structures of some selected antiviral Schiff bases and their complexes

excellent antimalarial activity $\left(\mathrm{IC}_{50}, 2.28-26.9\right.$ $\mu \mathrm{g} / \mathrm{mL}$ ). Compound 2.38 was the most potent antimalarial agent $\left(\mathrm{IC}_{50} 2.28 \mu \mathrm{g} / \mathrm{mL}\right)$, extending the benefits of morpholine ring in biological applications.

\section{Antiviral activity}

Viruses, with the exception of some few microorganisms that differ from prokaryotes and eukaryotes, have their genetic materials stored in ribonucleic acids (RNA) and not in deoxyribonucleic acids (DNA). Drug resistance by viruses is a serious public health issue and treatment of related infections calls for the search for novel bioactive compounds in addressing the problem.

A series of Schiff base ligands derived from 5amino-4-phenyl-4H-1,2,4-triazole-3-thiol and their metal complexes have been synthesized and evaluated for their antiviral properties. For example, Al-Masoudi et al [65] reported on the synthesis and antiviral activity of some Schiff bases against HIV-1 (strain IIIB) and HIV-2 (strain ROD) in human T-lymphocyte (MT-4) cells using the MT-4/MTT assay. The $\mathrm{EC}_{50}$ (effective concentration of compound $(\mu \mathrm{M})$ achieving $50 \%$ protection in MT-4 cell lines against the cytopathic effect of HIV) was established. It was found that tested strains were sensitive to the ligands and their complexes with greater activity observed in metal-based ligands. Compounds 2.41 and 2.42 (Figure 6) were the most potent anti-HIV agents studied from this series inhibiting replication in cell culture at $\mathrm{EC}_{50} 10.2 \mu \mathrm{g} / \mathrm{mL}$ against HIV-2 with an index selectivity of 9. Gold complex, compound 2.42 displayed higher antiviral activity than other complexes probably because gold has some antimicrobial property and Tweedy's theory may have as well influenced the membrane permeability.

Kumar et al [66] synthesized Schiff bases of 3(benzylideneamino)-2-phenylquinazoline-4(3H)ones through the formation of 3-amino-2-phenyl 
quinazoline-4(3) $\mathrm{H}$-one with various substituted carbonyl compounds. Antiviral activity against different viruses viz: herpes simplex virus-1 (KOS), herpes simplex virus-2, vaccinia virus, vesicular stomatitis virus, herpes simplex virus-1 TK- KOS ACVr, para influenza-3 virus, reovirus1 , Sindbis virus, and seven others were carried out. The efficacy of the ligands to alter the process of respiration in each viral representative was compared to brivudine, ribavirin, cidofovir, ganciclovir used as reference materials.

The studied microorganisms reacted differently when exposed to the test compounds with some displaying more sensitivity to the prepared Schiff bases than the controls. Herpes simplex virus-1, herpes simplex virus-2, herpes simplex virus- 1 and vaccinia virus in human embryonic lung cell culture were very sensitive to compound $\mathbf{2 . 4 3}$ (Figure 6) exhibiting $50 \%$ cell death at $\mathrm{EC}_{50}$ ranged of $0.8-30 \mu \mathrm{g} / \mathrm{mL}$ greater than the positive controls $\left(E_{50}, 0.05-250 \mu \mathrm{g} / \mathrm{mL}\right.$ ). The methoxy-substituted (2.44) and unsubstituted (2.45) analogs of compound 2.43 also exhibited better antiviral properties in comparison to the standards.

A study by Sriram et al [67] described the synthesis of Schiff bases derived from abacavir prodrugs with substituted benzaldehyde and ketone derivatives using microwave irradiation. The ability of the compounds to inhibit the replication of HIV-1 in CEM cell lines and $E_{50}$ and $\mathrm{CC}_{50}$ (cytotoxic concentration of compound $(\mu \mathrm{M})$ required to reduce the viability of mockinfected CEM cells by $50 \%$ ) were determined. Abacavir and synthesized ligands exhibited excellent anti-HIV activity, particularly compounds $2.43-2.51$ were found to be highly active against HIV. Substituted benzaldehyde derivatives were more active than ketone analogs. Compound 2.48 displayed the strongest inhibitory property with $\mathrm{EC}_{50}$ of $0.05 \mu \mathrm{M}, \mathrm{CC}_{50}>$ $100 \mu \mathrm{M}$, a selectivity index (SI) > 2000, and observed to be 32 times more potent than the parent drug $\left(\mathrm{EC}_{50}, 1.6 \mu \mathrm{M}\right)$. It was also recorded that the lipophilicity of the ligands significantly increased their pharmacological properties.

\section{CONCLUSION}

Undoubtedly, Schiff bases have good biological properties and the ability of heteroatoms containing Schiff bases to form complexes with metal ions is an added advantage to their pharmacophore properties. It is necessary to bring together those Schiff bases and metalbased Schiff base compounds that have demonstrated significant biological properties for modification towards future drug development as microorganisms turn to nullify the effectiveness of current antibiotics and antimicrobial agents through resistance and adaptation.

\section{DECLARATIONS}

\section{Acknowledgement}

The authors are thankful to the University of Johannesburg for funding this work through the Global Excellence and Stature (GES) Masters' and Doctorate Scholarships.

\section{Conflict of interest}

The authors declare no conflict of interests.

\section{Contribution of authors}

We declare that this work was done by the authors named in this article and all liabilities pertaining to claims relating to the content of this article will be borne by the authors. In addition, a declaration of the role of each author is as provided. Mr. Thierry $\mathrm{Y}$ Fonkui put the manuscript all together and wrote the initial draft of the paper, Dr. Monisola I Ikhile conceived and co-supervised the study; Professors Derek T Ndinteh and Patrick B Njobeh designed, supervised and edited the work. All authors read and approved the manuscript for publication.

\section{REFERENCES}

1. Tidwell TT. Hugo (Ugo) Schiff, Schiff bases, and a century of $\beta$-lactam synthesis. Angew Chem Int Ed. 2008;47: 1016-1020.

2. Cimerman Z, Snežana M, Nives G. Schiff bases derived from aminopyridines as spectrofluorimetric analytical reagents. Croat Chem Acta. 2000;73: 85-96.

3. Qin W, Sha L, Panunzio M, Biondi S. Schiff Bases: $A$ Short Survey on an Evergreen Chemistry Tool. Molecules. 2013;18: 12264-12289.

4. Abdel-Magid AF, Carson KG, Harris BD, Maryanoff $C A$, Shah RD. Reductive Amination of aldehydes and ketones with sodium triacetoxyborohydride. studies on direct and indirect reductive amination procedures 1. J Org Chem. 1996;61: 3849-3862.

5. Anand P, Patil V., Sharma V., Khosa R., Masand N. Schiff bases: A review on biological insights. Int $J$ Drug Des Discov. 2012;3: 851-868.

6. Zhang $\mathrm{S}-\mathrm{H}$, Feng $\mathrm{C}$. Microwave-assisted synthesis, crystal structure and fluorescence of novel coordination complexes with Schiff base ligands. J Mol Struct. 2010;977: 62-66.

7. Neochoritis CG, Zarganes-Tzitzikas T, Tsoleridis CA, Stephanidou-Stephanatou J, Kontogiorgis CA, Hadjipavlou-Litina DJ, et al. One-pot microwave

Trop J Pharm Res, December 2018; 17(12): 2515 
assisted synthesis under green chemistry conditions, antioxidant screening, and cytotoxicity assessments of benzimidazole Schiff bases and pyrimido[1,2a]benzimidazol-3(4H)-ones. Eur J Med Chem. 2011;46: 297-306.

8. Thaker BT, Barvalia RS. Microwave-assisted synthesis and characterization of unsymmetrical tetradentate Schiff base complexes of $\mathrm{VO}(\mathrm{IV})$ and $\mathrm{MoO}(\mathrm{V})$. Spectrochim Acta A Mol Biomol Spectrosc. 2011;84: 51-61.

9. Maurya MR, Saini N, Avecilla F. Catalytic oxidation of secondary alcohols by molybdenum complexes derived from 4-acyl pyrazolone in presence and absence of an $\mathrm{N}$-based additive: Conventional versus microwave assisted method. Inorganica Chim Acta. 2015;438: 168178.

10. Bhagat S, Sharma N, Chundawat TS. Synthesis of Some Salicylaldehyde-Based Schiff Bases in Aqueous Media. J Chem. 2013;2013: 1-4.

11. Salve PS, Alegaon SG, Sriram D. Three-component, one-pot synthesis of anthranilamide Schiff bases bearing 4-aminoquinoline moiety as Mycobacterium tuberculosis gyrase inhibitors. Bioorg Med Chem Lett. 2017;27: 1859-1866.

12. Brodowska K, Correia I, Garribba E, Marques F, Klewicka E, Łodyga-Chruscińska E, et al. Coordination ability and biological activity of a naringenin thiosemicarbazone. $J$ Inorg Biochem. 2016;165: 36-48.

13. Rauf A, Shah A, Khan AA, Shah AH, Abbasi R, Qureshi $I Z$, et al. Synthesis, $p H$ dependent photometric and electrochemical investigation, redox mechanism and biological applications of novel Schiff base and its metallic derivatives. Spectrochim Acta A Mol Biomol Spectrosc. 2017;176: 155-167.

14. Jana S, Dalapati S, Guchhait N. Proton Transfer Assisted Charge Transfer Phenomena in Photochromic Schiff Bases and Effect of -NEt 2 Groups to the Anil Schiff Bases. J Phys Chem A. 2012;116: 10948-10958.

15. Naik $A D$, Fontaine $G$, Bellayer $S$, Bourbigot $S$. Crossing the Traditional Boundaries: Salen-Based Schiff Bases for Thermal Protective Applications. ACS Appl Mater Interfaces. 2015;7: 21208-21217.

16. Nag S, Mishra A, Batra S. A facile route to the synthesis of pyrimido[2,1-b]quinazoline core from the primary allyl amines afforded from Baylis-Hillman adducts. Tetrahedron. 2008;64: 10162-10171.

17. Neochoritis CG, Zarganes-Tzitzikas T, Tsoleridis CA, Stephanidou-Stephanatou J, Kontogiorgis $C A$, Hadjipavlou-Litina DJ, et al. One-pot microwave assisted synthesis under green chemistry conditions, antioxidant screening, and cytotoxicity assessments of benzimidazole Schiff bases and pyrimido[1,2a]benzimidazol-3(4H)-ones. Eur J Med Chem. 2011;46. 297-306.

18. Giovannoni MP, Ciciani G, Cilibrizzi A, Crocetti L, Daniele $S$, Di Cesare Mannelli $L$, et al. Further studies on pyrazolo[1',5':1,6]pyrimido[4,5-d]pyridazin-4(3H)-ones as potent and selective human $A 1$ adenosine receptor antagonists. Eur J Med Chem. 2015;89: 32-41.

19. El-Sayed NA, Awadallah FM, Ibrahim NA, El-Saadi MT. Synthesis, anti-inflammatory and ulcerogenicity studies of some substituted pyrimido[1,6-a]azepine derivatives. Eur J Med Chem. 2010;45: 3147-3154.

20. Zoubi WA. Biological Activities of Schiff Bases and Their Complexes: A Review of Recent Works. Int $\mathrm{J}$ Org Chem. 2013;03: 73-95.

21. Kajal A, Bala S, Kamboj S, Sharma N, Saini V. Schiff Bases: A Versatile Pharmacophore. J Catal. 2013;2013: $1-14$.

22. Kumar ST. Biological applications of Schiff base and its metal complexes-A Review. Int J Sci Res. 2014;3: 1254-1256.

23. Hu G, Wang G, Duan N, Wen X, Cao T, Xie S, et al. Design, synthesis and antitumor activities of fluoroquinolone C-3 heterocycles (IV): s-triazole SchiffMannich bases derived from ofloxacin. Acta Pharm Sin B. 2012;2: 312-317.

24. Wang BJ, Groziak MP. Recent developments in the chemistry of boron heterocycles. Advances in heterocyclic chemistry. Elsevier; 2016. pp. 47-90. Available: http://linkinghub.elsevier.com/retrieve/pii/S00 65272515000690

25. Mahire VN, Mahulikar PP. Facile one-pot clean synthesis of benzimidazole motifs: Exploration on bismuth nitrate accelerated subtle catalysis. Chin Chem Lett. 2015;26: 983-987.

26. Akhtar W, Khan MF, Verma G, Shaquiquzzaman M, Rizvi MA, Mehdi SH, et al. Therapeutic evolution of benzimidazole derivatives in the last quinquennial period. Eur J Med Chem. 2017;126: 705-753.

27. Bansal $Y$, Silakari $O$. The therapeutic journey of benzimidazoles: A review. Bioorg Med Chem. 2012;20: 6208-6236.

28. Hranjec M, Starčević K, Pavelić SK, Lučin P, Pavelić K, Karminski Zamola G. Synthesis, spectroscopic characterization and antiproliferative evaluation in vitro of novel Schiff bases related to benzimidazoles. Eur $J$ Med Chem. 2011;46: 2274-2279.

29. Yıldız M, Karpuz Ö, Zeyrek CT, Boyacıoğlu B, Dal H, Demir $N$, et al. Synthesis, biological activity, DNA binding and anion sensors, molecular structure and quantum chemical studies of a novel bidentate Schiff base derived from 3,5-bis(triflouromethyl)aniline and salicylaldehyde. J Mol Struct. 2015;1094: 148-160.

30. Zhang L, Addla D, Ponmani J, Wang A, Xie D, Wang Y$N$, et al. Discovery of membrane active benzimidazole quinolones-based topoisomerase inhibitors as potential DNA-binding antimicrobial agents. Eur J Med Chem. 2016;111: 160-182.

31. Göker H, Kuş C, Boykin DW, Yildiz S, Altanlar N. Synthesis of some new 2-substituted-phenyl-1Hbenzimidazole-5-carbonitriles and their potent activity against Candida species. Bioorg Med Chem. 2002;10: 2589-2596. 
32. Vicini $P$, Geronikaki $A$, Incerti $M$, Busonera $B$, Poni $G$, Cabras $C A$, et al. Synthesis and biological evaluation of benzo[d]isothiazole, benzothiazole and thiazole Schiff bases. Bioorg Med Chem. 2003;11: 4785-4789.

33. Vicini $P$, Incerti $M$, Doytchinova IA, La Colla $P$, Busonera $B$, Loddo $R$. Synthesis and antiproliferative activity of benzo[d]isothiazole hydrazones. Eur $\mathrm{J}$ Med Chem. 2006;41: 624-632.

34. Kumar D, Jacob MR, Reynolds MB, Kerwin SM. Synthesis and evaluation of anticancer benzoxazoles and benzimidazoles related to UK-1. Bioorg Med Chem. 2002;10: 3997-4004.

35. Paramashivappa R, Phani Kumar P, Subba Rao PV, Srinivasa Rao A. Design, synthesis and biological evaluation of benzimidazole/benzothiazole and benzoxazole derivatives as cyclooxygenase inhibitors. Bioorg Med Chem Lett. 2003;13: 657-660.

36. Sondhi S, Bhattacharjee G, Jameel $R$, Shukla $R$ Raghubir $R$, Lozach $O$, et al. Anti-inflammatory, analgesic and kinase inhibition activities of some acridine derivatives. Open Chem. 2004;2: 1-15.

37. Sondhi SM, Singh N, Kumar A, Lozach O, Meijer L. Synthesis, anti-inflammatory, analgesic and kinase (CDK-1, CDK-5 and GSK-3) inhibition activity evaluation of benzimidazole/benzoxazole derivatives and some Schiff's bases. Bioorg Med Chem. 2006;14: 3758-3765.

38. El-wakiel N, El-keiy M, Gaber M. Synthesis, spectral, antitumor, antioxidant and antimicrobial studies on $\mathrm{Cu}(\mathrm{II}), \mathrm{Ni}(\mathrm{II})$ and $\mathrm{Co}(\mathrm{II})$ complexes of $4-[(1 \mathrm{H}-$ Benzoimidazol-2-ylimino)-methyl]-benzene-1,3-diol. Spectrochim Acta A Mol Biomol Spectrosc. 2015;147: 117-123.

39. Zawawi NKNA, Taha M, Ahmat N, Wadood A, Ismail NH, Rahim $F$, et al. Benzimidazole derivatives as new $\alpha$ glucosidase inhibitors and in silico studies. Bioorganic Chem. 2016;64: 29-36.

40. Myer L, Denny L, Telerant R, Souza M de, Wright TC, Kuhn $L$. Bacterial vaginosis and susceptibility to HIV infection in South African women: a nested case-control study. J Infect Dis. 2005;192: 1372-1380.

41. Coetzee E, Rode H, Kahn D. Pseudomonas aeruginosa burn wound infection in a dedicated paediatric burns unit. S Afr J Surg. 2013;51: 50-53. Available: http://sajs.redbricklibrary.com/index.php/sajs/article/view $/ 1791$

42. Rajabally NM, Pentecost M, Pretorius G, Whitelaw A, Mendelson $M$, Watermeyer $G$. The Clostridium difficile problem: A South African tertiary institution's prospective perspective. S Afr Med J. 2013;103: 168172.

43. Crowther-Gibson P, Govender N, Lewis DA, Bamford C, Brink A, Gottberg A von, et al. Part IV. GARP: Human infections and antibiotic resistance. S Afr Med J. 2011;101: 567-578. Available: http://www.samj.org.za/ index.php/samj/article/view/5102

44. Shanty AA, Philip JE, Sneha EJ, Prathapachandra Kurup MR, Balachandran S, Mohanan PV. Synthesis, characterization and biological studies of Schiff bases derived from heterocyclic moiety. Bioorganic Chem. 2017;70: 67-73.

45. Singh AK, Pandey OP, Sengupta SK, Synthesis, spectral and antimicrobial activity of Zn(II) complexes with Schiff bases derived from 2-hydrazino-5-[substituted phenyl]1,3,4-thiadiazole and benzaldehyde/2-hydroxyacetophenone/indoline-2,3-dione. Spectrochim. Acta. A. Mol. Biomol. Spectrosc. 2013;113: 393-399.

46. More G, Raut D, Aruna K, Bootwala S. Synthesis, spectroscopic characterization and antimicrobial activity evaluation of new tridentate Schiff bases and their Co(II) complexes. J Saudi Chem Soc. 2017;

47. Salehi M, Ghasemi F, Kubicki M, Asadi A, Behzad M, Ghasemi MH, et al. Synthesis, characterization, structural study and antibacterial activity of the Schiff bases derived from sulfanilamides and related copper(II) complexes. Inorganica Chim Acta. 2016;453: 238-246.

48. Eucast Definitive Document E.Def 3.1. Determination of minimum inhibitory concentrations (MICs) of antibacterial agents by agar dilution. Clin Microbiol Infect. 2000;6: 509-515.

49. Moussa A, Noureddine D, Mohamed HS, Abdelmelek M, Saad A. Antibacterial activity of various honey types of Algeria against Staphylococcus aureus and Streptococcus pyogenes. Asian Pac J Trop Med. 2012;5: 773-776.

50. Hazra M, Dolai T, Pandey A, Dey SK, Patra A. Synthesis and characterisation of Copper(II) complexes with tridentate NNO functionalized ligand: density function theory study, DNA binding mechanism, optical properties, and biological application. Bioinorg Chem Appl. 2014;2014: 1-13.

51. van de Waterbeemd $H$, Smith $D A$, Beaumont $K$, Walker DK. Property-based design: Optimization of drug absorption and pharmacokinetics. I Med Chem. 2001;44: 1313-1333.

52. Njobeh PB, Dutton MF, Koch SH, Chuturgoon A, Stoev $S$, Seifert K. Contamination with storage fungi of human food from Cameroon. Int J Food Microbiol. 2009;135: 193-198.

53. Whitlow L. Evaluation of Mycotoxin Binders. Proceeding 4th Mid-Atlantic Nutrution conference. Ed. USA; 2006: 132-143.

54. Diaz DE, Hagler WM, Blackwelder JT, Eve JA, Hopkins $B A$, Anderson KL, et al. Aflatoxin binders II: reduction of aflatoxin $M 1$ in milk by sequestering agents of cows consuming aflatoxin in feed. Mycopathologia. 2004;157: 233-241.

55. García-Pérez OD. Effectiveness of aluminosilicate-based products for detoxification of aflatoxin-contaminated diets for juvenile Pacific white shrimp, Litopenaeus vannamei. Cienc Mar. 2013;39: 1-13.

56. Maddila S, Gorle S, Seshadri N, Lavanya $P$, Jonnalagadda SB. Synthesis, antibacterial and antifungal activity of novel benzothiazole pyrimidine derivatives. Arab J Chem. 2016;9: 681-687.

57. Asati V, Sahu NK, Rathore A, Sahu S, Kohli DV. Synthesis, characterization and antimicrobial evaluation

Trop J Pharm Res, December 2018; 17(12): 2517 
of some 1,3-benzothiazole-2-yl-hydrazone derivatives. Arab J Chem. 2015;8: 495-499.

58. Joseyphus RS, Nair MS. Antibacterial and antifungal studies on some Schiff base complexes of Zinc(II). Mycobiology. 2008;36: 93.

59. Dharmaraj N, Viswanathamurthi $P$, Natarajan $K$. Ruthenium(II) complexes containing bidentate Schiff bases and their antifungal activity. Transit Met Chem. 2001; 105-109.

60. Supuran CT, Scozzafava A. Carbonic anhydrases as targets for medicinal chemistry. Bioorg Med Chem. 2007; 15: 4336-4350.

61. Katwal R, Kaur H, Kapur BK. Applications of copper Schiff's base complexes: a review. Sci Rev Chem Commun. 2013;3: 1-15.

62. Krungkrai SR, Suraveratum N, Rochanakij S, Krungkrai $J$. Characterisation of carbonic anhydrase in Plasmodium falciparum. Int J Parasitol. 2001;31: 661668.

63. Sharma $M$, Chauhan $K$, Srivastava RK, Singh SV, Srivastava K, Saxena JK, et al. Design and synthesis of a new class of 4-Aminoquinolinyl- and 9-Anilinoacridinyl Schiff base hydrazones as potent antimalarial agents. Chem Biol Drug Des. 2014;84: 175-181.

64. Jarrahpour $A$, Shirvani $P$, Sharghi $H$, Aberi $M$, Sinou $V$, Latour $C$, et al. Synthesis of novel mono- and bis-Schiff bases of morpholine derivatives and the investigation of their antimalarial and antiproliferative activities. Med Chem Res. 2015;24: 4105-4112.

65. Al-Masoudi NA, Aziz NM, Mohammed AT. Synthesis and In vitro anti-HIV activity of some new Schiff base ligands derived from 5-Amino-4-phenyl-4 H -1,2,4-triazole-3thiol and their metal complexes. Phosphorus Sulfur Silicon Relat Elem. 2009;184: 2891-2901.

66. Kumar KS, Ganguly S, Veerasamy R, De Clercq E. Synthesis, antiviral activity and cytotoxicity evaluation of Schiff bases of some 2-phenyl quinazoline-4(3)H-ones. Eur J Med Chem. 2010;45: 5474-5479.

67. Sriram D, Yogeeswari P, Myneedu NS, Saraswat V. Abacavir prodrugs: Microwave-assisted synthesis and their evaluation of anti-HIV activities. Bioorg Med Chem Lett. 2006;16: 2127-2129. 